\title{
Sodium-Potassium Cotransport in Hypertension and Hypotension
}

\author{
Misao Imagawa, M.D. and Kikuo Arakawa, M.D.
}

\section{Summary}

Furosemide-sensitive Na-K cotransport was measured as zerotrans efflux of each ion from fresh or $\mathrm{Na}$ loaded erythrocytes in normotensives $(n=34)$, essential $(n=41)$ or secondary $(n=12)$ hypertensives and essential $(n=17)$ or secondary $(n=5)$ hypotensives.

The stoichiometry of $\mathrm{Na}$ and $\mathrm{K}$ efflux was $0.9: 1$ in fresh cells and $1: 1$ in cells loaded with sufficient $\mathrm{Na}$ to give near the maximum velocity (Vmax) in a combined analysis.

There was a tendency toward a negative correlation between the Vmax of $\mathrm{Na}$ efflux and serum total cholesterol $(p=0.09)$ in the whole and it was significant in normotensives $(r=-0.60)$. Vmax of $\mathrm{Na}$ efflux also negatively correlated to age $(\mathrm{p}<0.01)$. After adjustment for age and total cholesterol level, essential hypertensives had a significantly $(p<0.01)$ higher mean $V \max$ of $\mathrm{Na}$ efflux $(0.657 \pm 0.029 \mathrm{mM} / 1 \mathrm{cells} / \mathrm{hr})$ than normotensives $(0.388 \pm 0.045)$, while essential hypotensives had a lower value $(0.212 \pm 0.047)(\mathrm{p}<$ 0.01 ).

$\mathrm{Na}$ efflux from fresh cells adjusted for internal $\mathrm{Na}$ content was higher in essential hypertensives $(0.173 \pm 0.018)$ than in normotensives $(0.107 \pm 0.026)(\mathrm{p}<0.05)$.

Thus, elevated cotransport was linked to essential hypertension and reduced cotransport to hypotension. Whether it is a cause or a result remains to be further investigated.

\section{Additional Indexing Words:}

Age Serum total cholesterol Na loaded erythrocyte Fresh cell Zero-trans efflux Japanese

7 HE classic and current proposition that salt plays a key role in the regulation of blood pressure level has attracted numerous epidemiological, clinical and experimental concerns. A clue to the explanation may be found in a hypothesis proposed by Blaustein" that a high ccllular $\mathrm{Na}$ conccntration

From the Department of Internal Medicine, Fukuoka University School of Medicine, Fukuoka, Japan.

Address for reprint: Kikuo Arakawa, M.D., Department of Internal Medicine, Fukuoka University School of Medicine, Nanakuma 7-45-1, Fukuoka 814-01, Japan.

Received for publication July 18, 1985. 
induces an elevated $\mathrm{Ca}$ level via $\mathrm{Na}-\mathrm{Ga}$ exchange, and increases vascular muscle tension leading to high blood pressure. It was also important in reassessing an earlier hypothesis of the natriuretic factor ${ }^{2)}$ and coupling with the concept of a circulating Na pump inhibitor by Haddy ${ }^{3}$ ) Indecd, recent ever-accumulating evidence of the presence of endogenous digoxin-like substances $^{41,5)}$ do provide these ideas with material proof.

In contrast to the possible role of the $\mathrm{Na}$ pump, the major $\mathrm{Na}$ transport system of cells, the minor pathways such as $\mathrm{Na}-\mathrm{Na}(\mathrm{Li})$ countertransport ${ }^{6), 71}$ or Na-K cotransport ${ }^{8), 9)}$ are less clearly linked to the pathogenesis of hypertension. Although there are considerable controversies about even the basic properties of these minor systems, clinical interests cannot but force us to search for better understanding.

The so-called Na-K cotransport system is a member of the loop diureticssensitive chloride transport system ${ }^{10}$-12) which is widespread in the various secretory and absorptive epithelia, ${ }^{13), 14)}$ smooth muscle cells, ${ }^{15)-17)}$ blood cells, nerves ${ }^{18)}$ and even brain capillary endothelial cells. ${ }^{19)}$

Many studies on the relationship between essential hypertension and this transport system of the erythrocyte membrane, the most representative biomembrane available, have failed to come to an agreement partially because of the assumption of its solely genetic regulation.9),20) Recent reports on several modulators ${ }^{21)-25)}$ urge us to take this aspect into consideration.

In the present investigation, we studied the estimated maximum rate of outward cotransport in erythrocytes from patients with various disorders of blood pressure regulation, adjusting for age, and serum total cholesterol that was expected to indicate membrane cholesterol content to some degree. We chose as subjects not only hypertensives and normotensives but also hypotensives to enhance the contrast by comparing the extremes of the blood pressure spectrum and thereby to ascertain the role of the cotransport system in blood pressure regulation.

\section{Subjects AND Methods}

We studied 41 essential hypertensives (EHT), 12 secondary hypertensives (SHT) (5 renovascular hypertension, 1 idiopathic aldosteronism, 2 Cushing's syndrome and 4 renoparenchymal hypertension), 17 essential hypotensives (eht) and 5 secondary hypotensives ( 1 case each of Addisonism, Bartter's syndrome, Pseudo-Bartter's syndrome, chronic obstructive lung disease and Shy-Drager syndrome). The control group was 34 normotensives (NT). Age and mean blood pressure (MBP) on the day of blood sampling of each subject group are listed in Table I. 
Table I. Age and Mean Blood Pressure (MBP) of Each Group

\begin{tabular}{c|c|c|c|c|c}
\hline \multicolumn{1}{c|}{ Group } & NT & EHT & SHT & eht & sht \\
\hline $\begin{array}{l}\text { male } \\
\text { fernale }\end{array}$ & 3422 & 41 28 & 126 & 611 & 4 \\
age (yrs) & 12 & 13 & 6 & 17 & 1 \\
range & $16-60$ & $18-68$ & $23-43$ & $22-47$ & $25-75$ \\
mean (SE) & $36.7(2.1)$ & $44.7(2.1)$ & $34.7(2.2)$ & $37.2(2.2)$ & $48.2(8.7)$ \\
MBP (mmHg) & & & & & \\
mean (SE) & $85.8(1.4)$ & $108.0(2.4)$ & $108.4(4.9)$ & $71.0(1.3)$ & $70.2(3.3)$
\end{tabular}

None of the subjects except 1 SHT (chr. glomerulonephritis) had severe renal impairment (GFR $<40 \mathrm{ml} / \mathrm{min}$ ). All hypertensives were inpatients on mild salt restriction (diet $\mathrm{NaCl} 6 \mathrm{~g} /$ day). Three of them were receiving antihypertensive drugs ( $\beta$-blocker, Angiotensin I converting enzyme inhibitor and $\mathrm{Ca}$ antagonist). Hypotensives and normotensives were on a free diet. None of the NT, SHT, eht or sht had family histories of hypertension in first-degree relatives. All subjects were Japanese.

Hypertension was defined as ambulatory diastolic blood pressure above $95 \mathrm{mmHg}$ and hypotension as systolic blood pressure below $100 \mathrm{mmHg}$.

Preparation of erythrocytes

Venous blood, collected in heparinized tubes after an overnight fast, was immediately centrifuged at $1,080 \mathrm{~g}$ for $10 \mathrm{~min}$ and the plasma and buffy coat were aspirated. Erythrocytes were then washed twice with an isotonic choline chloride medium containing choline chloride $150 \mathrm{mM} / 1$, glucose $10 \mathrm{mM} / 1$ and imidazole-HCl $20 \mathrm{mM} / \mathrm{l}(\mathrm{pH} \mathrm{7.4})$ at $4^{\circ} \mathrm{C}$. A known volume of the washed cells was set aside to measure in tracellular $\mathrm{Na}, \mathrm{K}$ and hemoglobin concentrations.

\section{Na loading}

Intracellular $\mathrm{Na}$ and $\mathrm{K}$ contents were exchanged using the PCMBS (2,5-p-chloromercuribenzenesulfonate) method described by Garrahan and Rega. ${ }^{26)}$ Washed cells were suspended and kept in a $\mathrm{Na}$ loading medium to give a hematocrit of $5 \%$ for $20 \mathrm{hrs}$ at $4{ }^{\circ} \mathrm{C}$. The loading medium contained

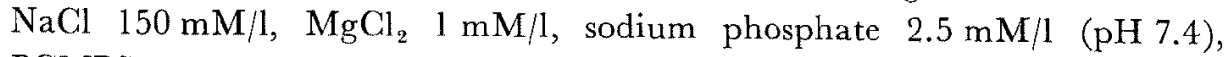
PCMBS $0.02 \mathrm{mM} / 1$ and EGTA [ethyleneglycol-bis (beta-amino-ethyl ether) $\mathrm{N}, \mathrm{N}^{\prime}$-tetra-acetic acid] $1 \mathrm{mM} / \mathrm{l}(\mathrm{pH} 7.4$ with Trizma base). It was renewed once after 6-8 hrs.

Sealing step

PCMBS treated cells were spun down and washed at $4^{\circ} \mathrm{C}$ twice with the isotonic choline chloride medium and once with a sealing medium containing $\mathrm{NaCl} 145 \mathrm{mM} / \mathrm{l}, \mathrm{KCl} 5 \mathrm{mM} / 1$, sodium phosphate $5.4 \mathrm{mM} / 1\left(\mathrm{pH} 7.4,37^{\circ} \mathrm{C}\right)$, 
$\mathrm{MgCl}_{2} 1 \mathrm{mM} / \mathrm{l}$, glucose $10 \mathrm{mM} / 1$, inosine $3 \mathrm{mM} / 1$, adenine $2 \mathrm{mM} / 1$ and cysteine $4 \mathrm{mM} / 1$, adjusted to final $\mathrm{pH} 7.4$ with Trizma base. Then the cells were suspended in the sealing medium to give a hematocrit of $10 \%$, and incubated at $37^{\circ} \mathrm{C}$ for $1 \mathrm{hr}$.

\section{Assay for $\mathcal{N} a-K$ cotransport}

Sealed cells (or fresh cells) were washed 3 times with the isotonic choline chloride medium and resuspended in $0.1 \mathrm{mM} / 1$ ouabain-added isotonic choline chloride medium $\left(\mathrm{MgCl}_{2}\right.$-sucrose medium was not chosen because of the inhibitory effect of $\mathrm{Mg}^{++}$on this transport system $)^{27)}$ with or without 1 $\mathrm{mM} / \mathrm{l}$ furosemide ( $\mathrm{pH} 7.4$ with Trizma base) to give a hematocrit of $5 \%$, and then incubated for $0,0.5,1.5$ and $2.5 \mathrm{hrs}$ at $37^{\circ} \mathrm{C}$.

After each incubation period, cells were spun down at $4^{\circ} \mathrm{C}$ at $1,080 \mathrm{~g}$ for $10 \mathrm{~min}$ and the $\mathrm{Na}, \mathrm{K}$ and hemoglobin concentrations of the supernatant and cells were measured. Ouabain-insensitive, furosemide-sensitive $\mathrm{Na}$ and $\mathrm{K}$ effluxes were calculated from the difference between each flux in the absence and presence of furosemide. It is generally accepted that PCMBS does not affect cotransport. ${ }^{28)}$

$\mathrm{Na}$ and $\mathrm{K}$ concentrations were measured by flame photometry (Japan Spectroscopic Co. Ltd., Flame-30). Hemoglobin was estimated as oxyhemoglobin by measuring light absorption at $541 \mathrm{~nm}$.

PCMBS, ouabain and cysteine were bought from Sigma Chemical Company (St. Louis, Missouri). Furosemide was a gift from Hoechst Japan Pharmaceutical, Inc. (Tokyo, Japan).

\section{Measurement of other parameters}

The following parameters were also measured for some subjects: plasma renin activity (PRA) and plasma aldosterone concentration (PAG) by

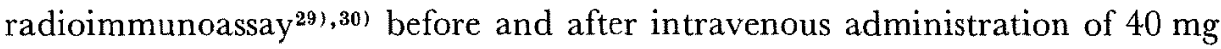
of furosemide; plasma catecholamines by trihydroxyindole (THI) method using high performance liquid chromatography; ${ }^{31)}$ and serum total cholesterol by the enzymatic method. ${ }^{32}$ )

\section{Statistical methods}

Analysis of covariance was applied when adjustment for covariants was needed. Statistical analysis was done using the Statistical Analysis System (SAS). ${ }^{33)}$

Since data were not always available for each subject, the number of subjects varied with the analysis.

\section{RESULTS}

Since the separate investigations for males and females in each of the 
Table II. Means and Standard Errors of Cation Contents of Erythrocytes Prepared for Assay of Cotransport

\begin{tabular}{|c|c|c|c|c|c|c|}
\hline \multirow{2}{*}{ Group } & \multicolumn{3}{|c|}{ Fresh cells (mM/l cells) } & \multicolumn{3}{|c|}{ Loaded cells ( $\mathrm{mM} / 1$ cells) } \\
\hline & $\mathrm{n}$ & $\mathrm{Na}$ & K & $\mathrm{n}$ & $\mathrm{Na}$ & $\mathrm{K}$ \\
\hline NT & 8 & $8.9 \pm 0.4$ & $101.9 \pm 1.7$ & 34 & $54.3 \pm 1.5$ & $52.7 \pm 1.8$ \\
\hline EHT & 18 & $9.9 \pm 0.4$ & $103.2 \pm 1.4$ & 41 & $52.4 \pm 1.3$ & $53.4 \pm 1.3$ \\
\hline SHT & 6 & $8.8 \pm 0.7$ & $101.9 \pm 2.8$ & 11 & $48.7 \pm 1.7$ & $57.5 \pm 1.6$ \\
\hline eht & 1 & 8.9 & 108.3 & 17 & $49.8 \pm 1.9$ & $58.4 \pm 2.6$ \\
\hline sht & - & - & & 5 & $52.4 \pm 5.0$ & $51.7 \pm 3.8$ \\
\hline
\end{tabular}

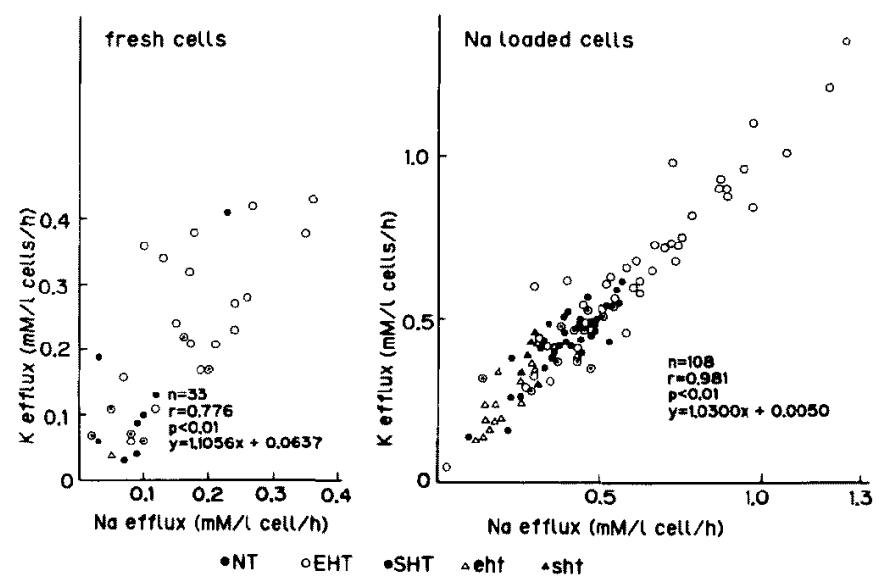

Fig. 1. The relationship between $\mathrm{Na}$ and $\mathrm{K}$ efflux from fresh cells (left), and $\mathrm{Na}$ loaded cells (right) in each group. The linear regressions among the respective 4 and 5 groups were not significantly different in terms of either the slope or the intercept, and the data from all the groups were combined.

following analyses confirmed no major differences between sexes, the combined data of both sexes are presented.

\section{Cation content}

Table II shows the cation contents of $\mathrm{Na}$ loaded cells from each group. No significant difference was observed among them. Those of some fresh cells for which cation efflux was measured directly without $\mathrm{Na}$ loading are also presented.

\section{Stoichiometry of $\mathrm{Na}$ and $K$ efflux}

Fig. 1 shows the relationship between $\mathrm{Na}$ and $\mathrm{K}$ effluxes from fresh cells (left) and $\mathrm{Na}$ loaded cells (right). Analysis of covariance showed no significant difference among the linear regressions of the groups in tcrms of the slope $(\mathrm{p}=0.66$ and 0.53 , respectively) and the intercept $(\mathrm{p}=0.83$ and 0.79 , respectively). The data of all the groups were, therefore, combined to obtain the 


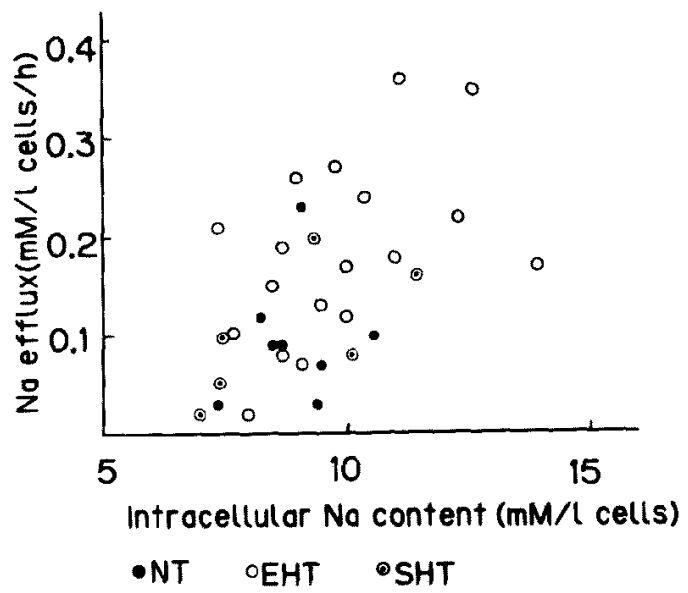

Fig. 2. The relationship between intracellular Na content and $\mathrm{Na}$ efflux from fresh cells. Linear regression coefficients were not significantly different among the 3 groups $(p=0.90)$. The pooled regression coefficient was 0.0246 $(\mathrm{p}<0.01)$.

Table III. Means and Standard Errors of Furosemide-Sensitive Na Efllux from Fresh Cells Adjusting for Intracellular $\mathrm{Na}$

\begin{tabular}{l|r|r|r|r}
\hline \multicolumn{1}{c|}{ Group } & $\mathrm{n}$ & Na efflux $(\mathrm{mM} / \mathrm{l}$ cells/hr) & $\mathrm{p}^{\mathrm{a}}$ & $\mathrm{p}^{\mathrm{b}}$ \\
\hline $\mathrm{NT}$ & 8 & $0.107 \pm 0.026$ & - & \\
EHT & 18 & $0.173 \pm 0.018$ & $<0.05$ & - \\
$\mathrm{SHT}$ & 6 & $0.117 \pm 0.030$ & 0.81 & 0.12
\end{tabular}

a NT vs EHT or SHT; b EHT vs SHT.

regression line.

The stoichiometry of $\mathrm{Na}$ and $\mathrm{K}$ efflux was $0.9: 1$ at low $\mathrm{Na}$ content of fresh cells and 1: 1 at sufficient $\mathrm{Na}$ content to ensure the maximum activation of loaded cells.

Cotransport in fresh cells

Fig. 2 shows the relationship between intracellular $\mathrm{Na}$ content and $\mathrm{Na}$ efflux from fresh cells. Although the mode of the activation of outward cotransport by intracellular $\mathrm{Na}$ is not fitted by a linear fashion, ${ }^{34)}$ we regarded it as linear in the narrow range of $\mathrm{Na}$ represented in our study. When $\mathrm{Na}$ effect was compared among NT, EHT and SHT by analysis of covariance, linear regression coefficients were not significantly different among the groups $(\mathrm{p}=0.90)$, and the pooled regression coefficient was statistically significant $(0.0246, \mathrm{p}<0.01)$.

Table III shows internal-sodium-adjusted means of $\mathrm{Na}$ efflux from fresh cells for each group. Mean Na efflux in EHT $(0.173 \pm 0.018 \mathrm{mM} / 1$ cells $/ \mathrm{hr})$ 


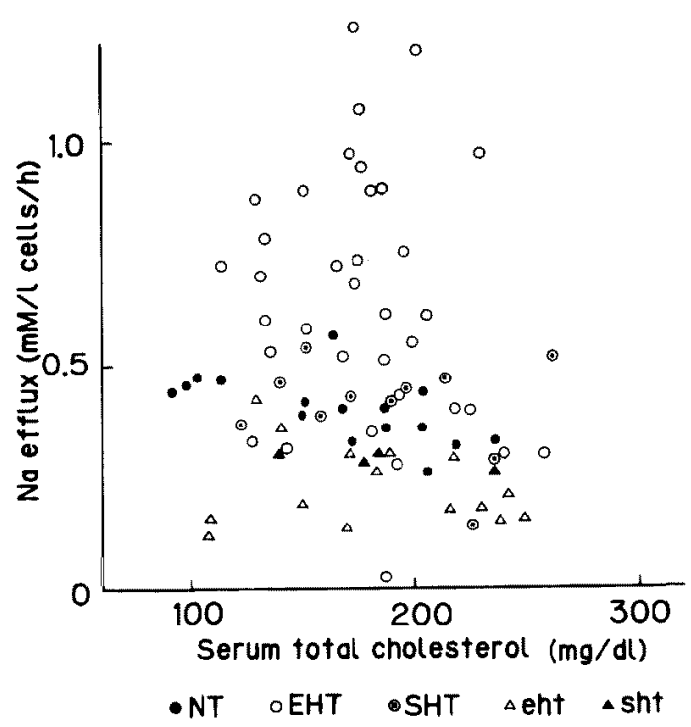

Fig. 3. The relationship between $\mathrm{Vmax}$ of $\mathrm{Na}$ efflux and serum total cholesterol. Linear regression coefficients were not significantly different among the groups $(\mathrm{p}=0.96)$. The pooled regression coefficient was -0.0009 $(p=0.09)$.

was significantly higher than that in NT $(0.107 \pm 0.026)(p<0.05)$. There was no statistically significant difference between SHT $(0.117 \pm 0.030)$ and NT or EHT.

\section{Cotransport in loaded cells}

Furosemide-sensitive $\mathrm{Na}$ and $\mathrm{K}$ efflux rates from loaded cells, all of which contained about $50 \mathrm{mM} / 1$ cells of both $\mathrm{Na}$ and $\mathrm{K}$, were regarded as giving near the maximum velocity $(\mathrm{V} \max ){ }^{34), 35)}$

As shown in Figs. 3 and 4, Vmax of $\mathrm{Na}$ efflux seemed to be related to both serum total cholesterol and age. Confirming the homogeneity of regression slopes among the groups, the pooled regression coefficients were evaluated. In all cases examined, the pooled regression coefficient between the $\mathrm{Vmax}$ of $\mathrm{Na}$ efflux and serum total cholesterol did not reach a significant level $(-0.0009, p=0.09)$, but there was a significant correlation in NT $(n=$ $16, r=-0.60, p<0.05)$. The pooled regression coefficient between the $V \max$ of $\mathrm{Na}$ efflux and age was statistically significant $(-0.0054, \mathrm{p}<0.01)$.

Since age and serum total cholesterol were different among the groups, both factors were controlled as covariates in comparing the Vmax of $\mathrm{Na}$ efflux among the groups. The age- and cholesterol-adjusted mean of the $\mathrm{Vmax}$ of $\mathrm{Na}$ efflux was significantly higher $(\mathrm{p}<0.01)$ in EHT $(0.657 \pm 0.029$ $\mathrm{mM} / \mathrm{l}$ cells $/ \mathrm{hr})$ than in NT $(0.388 \pm 0.045)$, while lower $(\mathrm{p}<0.01)$ in eht 


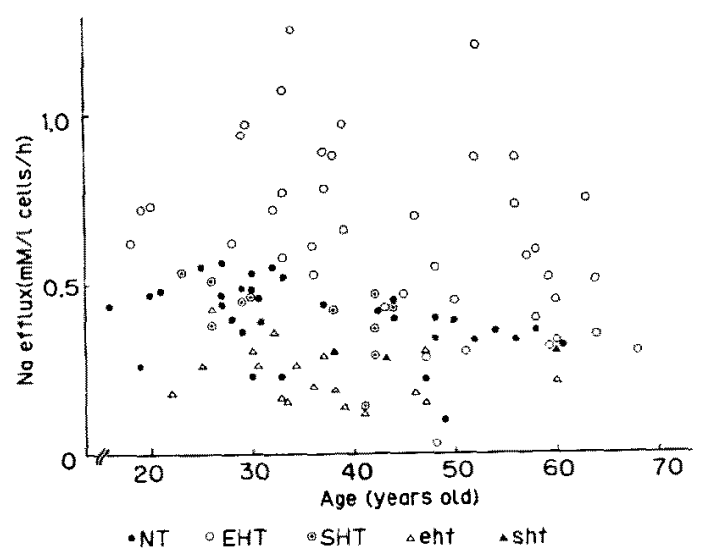

Fig. 4. The correlation between $\mathrm{Vmax}$ of $\mathrm{Na}$ efflux and age. Linear regression coefficients were not significantly different among the groups $(\mathrm{p}=$ $0.27)$. The pooled regression coefficient was statistically significant $(-0.0054$, $\mathrm{p}<0.01$ ).

Table IV. Means and Standard Errors of Na Efflux from Na Loaded Cells Adjusting for Age and Serum Total Cholesterol

\begin{tabular}{l|c|c|c|c|c}
\hline Group & $\mathrm{n}$ & Na efflux (mM/l cells/hr) & $\mathrm{p}^{\mathrm{a}}$ & $\mathrm{p}^{b}$ & $\mathrm{p}^{c}$ \\
\hline $\mathrm{NT}$ & 17 & $0.388 \pm 0.045$ & - & & \\
EHT & 40 & $0.657 \pm 0.029$ & $<0.01$ & - & \\
SHT & 11 & $0.374 \pm 0.056$ & 0.85 & $<0.01$ & - \\
eht & 15 & $0.212 \pm 0.047$ & $<0.01$ & & 0.46 \\
sht & 4 & $0.288 \pm 0.091$ & 0.33 & &
\end{tabular}

a NT va others; b EHT vs SHT; c eht vs sht.

$(0.212 \pm 0.047)$. EHT showed a higher mean Vmax than SHT $(0.374 \pm$ $0.056)(p<0.01)$. There was no significant difference between sht $(0.288 \pm$ 0.091 ) and NT or eht (Table IV).

There was no significant correlation between the Vmax of Na efflux and PRA, PAC, epinephrine or norepinephrine in any group.

\section{Drscussion}

The loop diuretics-sensitive, chloride-dependent $\mathrm{Na}-\mathrm{K}$ transport system in human erythrocytes appears to have somewhat complicated aspects. It mediates bidirectional 1:1 mutually-dependent Na-K (and perhaps $2 \mathrm{Cl}$ which is difficult to demonstrate owing to enormous flux) fluxes driven by the transmembrane gradient of each co-ion (even against its own), with or without $^{36)}$ net effects. In the latter case the idea of $1: 1$ exchange diffusion of 
both $\mathrm{Na}$ for $\mathrm{Na}$ and $\mathrm{K}$ for $\mathrm{K}$ could be introduced. ${ }^{37), 38)}$ The ouabain-resistant, furosemide-sensitive zero-trans efflux of $\mathrm{Na}$ and $\mathrm{K}$ that we are discussing is one of the simplest aspects of this system, and is usually called furosemidesensitive outward cotransport.

According to Garay et al, ${ }^{39)}$ the activation of this system by intracellular $\mathrm{Na}$ is fitted by a sigmoidal fashion, and the rate of $\mathrm{Na}$ transport is described by Hill's equation :

$$
\mathrm{V}=\frac{\mathrm{V} \max }{1+\left[\mathbf{K}_{50 \%} /\left(\mathrm{Na}_{\mathrm{i}}{ }^{+}\right)\right]^{\mathbf{n}}}
$$

where: Vmax is the maximum rate of outward $\mathrm{Na-K}$ cotransport; $\mathrm{K}_{50 \%}$ represents the intracellular $\mathrm{Na}$ concentration required for half-maximum outward cotransport stimulation and $\mathbf{n}$ is a cooperativity index (Hill's $\mathrm{n}$ ).

The cotransport rate at $20-25 \mathrm{mM} / \mathrm{l}$ cells of both inner $\mathrm{Na}$ and $\mathrm{K}$ was first reported to have been reduced in essential hypertensives by Garay et al, ${ }^{40}$ ) who attributed it to reduced Vmax in their earlier reports. More recently, they have pointed out abnormally high $\mathrm{K}_{50 \%}$ and compensatory increases in Vmax in some hypertensives. ${ }^{391,41)}$

Adragna et $\mathrm{al}^{35}$ found an elevated cotransport rate for inner $\mathrm{Na}$ and $\mathrm{K}$ at 50 and $60 \mathrm{mM} / 1$ cells respectively, which ensure at least $80-90 \%$ of the maximum activation, in hypertensives and normotensives with hypertensive relatives. However, except for an agreement that major racial differences seem to exist and blacks have lower cotransport rate than whites independent of the blood pressure level, ${ }^{42,}, 43$ many other reports are still controversial as to not only the outward cotransport rate at various inner cation compositions ${ }^{44), 45)}$ but also the inward one. ${ }^{46), 47)}$

It secms that, besides their belief in its genetic regulation they have taken no account of several other factors which may modulate this transport system. In the light of recent investigations, even if the density of the transport units is determined genetically, this system is also under the influences of cellular $\mathrm{Ca}^{++},{ }^{21)}$ cyclic AMP, ${ }^{21)}$ membrane cholesterol ${ }^{22)-24)}$ and cellular ATP, ${ }^{25)}$ with three of the former acting as inhibitors and the latter as a stimulator in human erythrocytes. In our study, erythrocytes were depleted of cyclic AMP and repleted with ATP in proportion to each reproducing capacity, and the influence of intracellular $\mathrm{Ca}^{++}$on the physiological level was assumed to be negligible, if any, compared with the drastic effect of Ca ionophore. Then only membrane cholesterol would not have been controlled.

The unesterified cholesterol (UEC) of erythrocytes is in equilibrium with that of plasma LDL and there is a positive correlation between the ratio of UEC to phospholipid of erythrocytes and that of plasma LDL. ${ }^{48}$ ) Although 
in our study only values of serum total cholesterol were available, a crude estimation of the amount of UEC of LDL is possible, and further, a similar estimation of that of erythrocytes may also be possible. Therefore, a tendency toward a negative correlation between serum total cholesterol and $\mathrm{Na}$ cotransport rate would be compatible with the inhibitory effect of erythrocyte UEC enriched in vivo ${ }^{23), 24)}$ or in vitro. ${ }^{22), 29)}$

Another correlation between age and cotransport rate may be due to the well-known relationship between age and LDL-cholesterol ${ }^{49}$ in part, but other factors could also have an influence. What is more interesting is that it reminds us of a report on the negative correlation between Na-Li countertransport and age. ${ }^{50)}$ In spite of persistent counterarguments, the idea that these two processes represent different modes of a single, highly complex transport system has been firmly supported.12),51) Hence, our result may suggest that they hold several modulators in common.

It is quite apparent that all these modulating factors should be controlled to compare the cotransport activity among various groups. Now that we have shown that cotransport is higher in essential hypertensives and lower in hypotensives after both age and cholesterol were adjusted, what does this mean?

Although the physiological role of this sytem in human erythrocytes has not been fully elucidated, its bidirectional operation is believed to cause net fluxes of ions driven by the net chemical potential represented as below: ${ }^{51}$ )

$$
\mu_{\text {net }}=\mathrm{RT} \ln \frac{\left[\mathrm{Na}_{\mathrm{e}^{+}}\right]\left[\mathrm{K}_{\mathrm{e}}{ }^{+}\right]\left[\mathrm{Cl}_{\mathrm{e}^{-}}\right]^{2}}{\left[\mathrm{Na}_{\mathrm{i}}{ }^{+}\right]\left[\mathrm{K}_{\mathrm{i}}{ }^{+}\right]\left[\mathrm{Cl}_{\mathrm{i}}\right]^{2}}
$$

where: $\mathrm{R}$ is gas constant;

$\mathrm{T}$ is absolute temperature;

$\left[\mathrm{Na}^{+}\right],[\mathrm{K}+]$ and $\left[\mathrm{Cl}^{-}\right]$are the respective internal (i) and external (e) concentrations.

Physiological compositions of internal and external $\mathrm{Na}$ and $\mathrm{K}$ are so critical for the direction of the net driving force that this system may function as a rapid regulator of intra or extracellular homeostasis; the higher the transport rate, the more rapid the approach to a new steady-state.

However, it seems unlikely that this function is directly related to blood pressure regulation. Therefore, we must assume that the cotransport activity is under a dynamic regulatory mechanism directed toward the minimum perturbation of the internal milieu, changing the number and/or the turnover rate of transport units. In this instance the elevated or reduced cotransport activity in vitro may indicate a compensatory response to the respective reduced or elevated activity in vivo, or to other environmental changes requir- 
ing correction, although we cannot identify any such particular change which has influence on blood pressure. Also, it seems that an elevated Vmax in essential hypertensives does not necessarily indicate a compensation for an abnormally high $\mathrm{K}_{50 \%}$ as proposed by Garay since essential hypertensives also showed an elevated cotransport rate at physiological cellular cation composition. In addition, one may question whether hydrostatic pressure per se has any thermodynamic effect on the transport activity. It is quite reasonable, but the effect of physiological pressure is thought to be almost negligible. ${ }^{52)}$ Actually, the difference in the cotransport activity between essential and secondary hypertensives in whom blood pressures were almost equal would refute the pressure effect.

On the other hand, there may be another interpretation based on the assumption that the cotransport system has the same kinetic behavior in different cell systems under final regulation by genetic factors. The function of the loop diuretics-sensitive chloride transport system is so differentiated, depending upon its specific localization in each tissue, as to allow it to participate in electrolyte absorption in Henle's loop, ${ }^{\text {53) }}$ salt uptake to the brain via the blood brain barrier, ${ }^{19}$ ) and maintenance of the higher than equilibrium $\mathrm{Cl}$-activity in vascular smooth muscle which may be related to muscle tension. ${ }^{16,17)}$ If the properties of this system in erythrocyte membranes are universal throughout the body, and fitted to these tissues, it might suggest the predisposition to salt retention, neuronal excitability ${ }^{53,54)}$ and vascular tension. While this generalization is fascinating, further study is needed for its clarification.

It is not clear whether the present findings reflect constitutional phenomena or responsive ones, but it seems to be meaningful that essential hypertensives and hypotensives showed contrasting behavior. Since we found a high incidence of elevated PRA, which was attributed to subclinical salt depletion, among essential hypotensives, ${ }^{55)}$ we have speculated that patients with essential hypotension have a genetic predisposition to somewhat impaired salt handling and therefore that this condition is a true counterpart of essential hypertension in its pathogenesis as far as salt metabolism is concerned. On the other hand, a spontaneously hypotensive strain of rats ${ }^{56}$ was developed by successive matings of the animals with the lowest systolic pressure for generations as were several genetically hypertensive strains. Most studies of the cotransport system do not address hypotension, but deal only with pathological hypertension. However, the clinical significance of salt handling may have varied with the change of salt intake, and essential hypotensives, probable beneficiaries in a salt-surfeited modern world, would have had a distinct handicap in salt-poor prehistoric times. Thus, essential hypertension and hypo- 
tension should be viewed as two deviations from the normal and both should be studied.

The relationship between the cotransport system and blood pressure regulation is still not clearly understood today, but the contrasting behaviors of the extremes of essential hypertension and hypotension as found in the present investigation may suggest a relation between them.

\section{ACKNOWLEDGMENTS}

The authors acknowledge Dr. Suminori Kono for help with the statistical analysis, Dr. Haruka Sasaki for referral of patients with Bartter's syndrome, Miss Tomoko Tanaka for skillful technical aid, and Hoechst Japan Pharmaceutical Inc. for supplying furosemide. This study was supported in part by a research grant-in-aid from the Ministry of Education, Science and Culture of Japan (B-58480246) and Fukuoka University Research Institute.

\section{REFERENCES}

1. Blaustein MP: Sodium ions, calcium ions, blood pressure regulation, and hypertension: a reassessment and a hypothesis. Am J Physiol 232: C165, 1977

2. De Wardener HE: The control of sodium excretion. in Handbook of Physiology, Renal Physiology, ed by Orloof J, Berliner RW, Am Physiol Soc, Washington, DC, p 677, 1973

3. Haddy FJ, Overbeck HW: Mini review; the role of humoral agents in volume expanded hypertension. Life Sci 19: 935, 1976

4. Gruber KA, Whitaker JM, Buckalew VM Jr: Endogenous digitalis-like substance in plasma of volume-expanded dogs. Nature 287: 743, 1980

5. Haupert GT Jr, Carilli GT, Cantley LC: Hypothalamic sodium-transport inhibitor is a high-affinity reversible inhibitor of $\mathrm{Na}^{+} \mathrm{K}^{+}-\mathrm{ATPase}$. Am J Physiol 247: F919, 1984

6. Hass M, Schooler J, Tosteson DC: Coupling of lithium to sodium transport in human red cells. Nature 258: 425, 1975

7. Canessa M, Adragna N, Solomon HS, Connolly TM, Tosteson DG: Increased sodium-lithium countertransport in red cells of patients with essential hypertension. New Engl J Med 302: 772,1980

8. Wiley JS, Cooper RA: A furosemide-sensitive cotransport of sodium plus potassium in the human red cell. J Clin Invest 53: 745, 1974

9. Garay RP, Dagher G, Pernollet MG, Devynck MA, Meyer P: Inherited defect in a $\mathrm{Na}^{+}$, $\mathrm{K}^{+}$-cotransport system in erythrocytes from essential hypertensive patients. Nature 284: 281, 1980

10. Chipperfield AR: Furosemide-sensitive (sodium and potassium) co-transport in human red cells: its dependence on chloride (T.o.). J Physiol 303: 62, 1980

11. Chipperfield AR: An effect of chloride on $(\mathrm{Na}+\mathrm{K})$ cotransport in human red blood cells. Nature 286: 281, 1980

12. Chipperfield AR: Chloride dependence of furosemide and phloretin-sensitive passive sodium and potassium fluxes in human red cells. J Physiol 312: 435, 1981

13. Warnock DG, Greger R, Dunham PB, Benjamin MA, Frizzell RA, Field M, Spring KR, Ives HE, Aronson PS, Seifter J: Ion transport processes in apical membranes of epithelia. Fed Proc 43: 2473, 1984

14. Reuss L, Lewis SA, Wills NK, Helman SI, Cox TC, Boron WF, Siebens AW, Guggino WB, Giebisch G, Schultz SG: Ion transport processes in basolateral membranes of epithelia. 
Fed Proc 43: 2488, 1984

15. Johns A, Cutshaw SV: Furosemide-sensitive thallium fluxes in smooth muscle of rabbit uterus. Am J Physiol 245: F778, 1983

16. Widdicombe $\mathrm{JH}$, Brading $\mathrm{AF}$ : A possible role of linked $\mathrm{Na}$ and $\mathrm{Cl}$ movement in active $\mathrm{Cl}$ uptake in smooth muscle. Pflügers Arch 386: 35, 1980

17. Kreye VAW, Bauer PK, Villhauer I: Evidence for furosemide-sensitive active chloride transport in vascular smooth muscle. Eur $\mathrm{J}$ Pharmacol 73: 91, 1981

18. Russell JM: Chloride in the squid giant axon. in Current Topics in Membranes and Transport, ed by Baker PF, Academic Press, London, p 177, 1984

19. Betz AL: Sodium transport from blood to brain: inhibition by furosemide and amiloride. J Neurochem 41: 1158, 1983

20. Davidson JS, Opie LH, Keding B: Sodium-potassium cotransport activity as genetic marker in essential hypertension. Br Med J 284: 539, 1982

21. Garay RP: Inhibition of the $\mathrm{Na}^{+} / \mathrm{K}^{+}$cotransport system by cyclic AMP and intracellular $\mathrm{Ca}^{2+}$ in human red cells. Biochim Biophys Acta 688: 786, 1982

22. Wiley JS, Cooper RA: Inhibition of cation cotransport by cholesterol enrichment of human red cell membranes. Biochim Biophys Acta 413: 425, 1975

23. Jackson PA, Morgan DB: The relation between membrane cholesterol and phospholipid and sodium efflux in erythrocytes from healthy subjects and patients with chronic cholestasis. Clin Sci 62: 101, 1982

24. Jackson P, Morgan DB: The relation between the membrane cholesterol content and anion exchange in the erythrocytes of patients with cholestasis. Biochim Biophys Acta 693: 99, 1982

25. Adragna NC, Perkins CM, Lauf PK: Furosemide-sensitive $\mathrm{Na}^{+}-\mathrm{K}^{+}$cotransport and cellular metabolism in human erythrocytes. Biochin Biophys Acta 812: 293, 1985

26. Garrahan PJ, Rega AF: Cation loading of red blood cells. J Physiol 193: 459, 1967

27. Rettori $O$, Lenoir JP: Ouabain-insensitive active sodium transport in erythrocytes: effect of external cation. Am J Physiol 222: 880, 1972

28. Wiater LA, Dunham PB: Passive transport of $\mathrm{K}^{+}$and $\mathrm{Na}^{+}$in human red blood cells; sulf hydryl binding agents and furosemide. Am J Physiol 245: C348, 1983

29. Ogihara $T$, Yamamoto $T$, Doi K, Omori K, Kumahara Y: Measurement of plasma renin activity by angiotensin I radioimmunoassay. Jpn J Nucl Med 10: 555, 1973

30. Goto U, Mori T, Kuroda Y, Arakawa K: Investigation for measurement of plasma aldosterone by ${ }^{125}$ I aldosterone RIA kit. Jpn J Clin Exp Med 54: 285, 1977

31. Kobayashi $\mathbf{H}$ : Measurement of plasma catecholamines by high performance liquid chromatography. SRL Hokan 2: 25, 1979 (in Japanese)

32. Allain CC, Poon LS, Chan CSG, Richmond W, Fu PC: Enzymatic determination of total serum cholesterol. Clin Chem 20: 470,1974

33. SAS Institute Inc: SAS user's guide: Statistics, 1982 Edition, SAS Institute Inc, Cary, North Carolina, 1982

34. Garay R, Adragna N, Canessa M, Tosteson D: Outward sodium and potassium cotransport in human red cells. J Membrane Biol 62: 169, 198 !

35. Adragna NC, Canessa ML, Solomon H, Slater E, Tosteson DC: Red cell lithium-sodium countertransport and sodium-potassium cotransport in patients with essential hypertension. Hypertension 4: 795, 1982

36. Brand SC, Whittam R: The effect of furosemide on sodium movements in human red blood cells. J Physiol 348: 301,1984

37. Dunn MJ: The effects of transport inhibitors on sodium outflux and influx in red blood cells: evidence for exchange diffusion. J Clin Invest 49: 1804, 1970

38. Duhm J, Göbel BO: Role of the furosemide-sensitive $\mathrm{Na}^{+} / \mathrm{K}^{+}$transport system in determining the steady-state $\mathrm{Na}^{+}$and $\mathrm{K}^{+}$content and volume of human erythrocytes in vitro and in vivo. J Membrane Biol 77: 243, 1984

39. Garay RP, Nazaret $\mathrm{C}$, Hannaert P, Price $\mathrm{M}$ : Abnormal $\mathrm{Na}^{+}, \mathrm{K}^{+}$cotransport function in 
a group of patients with essential hypertension. Eur J Clin Invest 13: 311, 1983

40. Dagher $\mathrm{G}$, Garay RP: A $\mathrm{Na}^{+}, \mathrm{K}^{+}$co-transport assay for essential hypertension. Can $\mathrm{J}$ Biochem 58: 1069, 1980

41. Price M, Hannaert P, Dagher $G$, Garay $\mathrm{RP}$ : Interaction of internal $\mathrm{Na}^{+}$and external $\mathrm{K}^{+}$ with the erythrocyte $\mathrm{Na}^{+}, \mathrm{K}^{+}$cotransport system in essential hypertension. Hypertension 6 : 352,1984

42. Tuck ML, Gross C, Maxwell MH, Brickman AS, Krasnoshtein G, Mayes D: Erythrocyte $\mathrm{Na}^{+}, \mathrm{K}^{+}$cotransport and $\mathrm{Na}^{+}, \mathrm{K}^{+}$pump in black and Caucasian hypertensive patients. Hypertension 6: 536,1984

43. Weder AB, Torretti BA, Julius S: Racial differences in erythrocyte cation transport. Hypertension 6: 115,1984

44. Swarts HGP, Bonting SL, de Pont JJHHM, Schuurmans Stekhoven JMAH, Thien TA, Van't Laar A: Cation fluxes and $\mathrm{Na}^{+}-\mathrm{K}^{+}$-activated ATPase activity in erythrocytes of patients with essential hypertension. Hypertension 3: 641, 1981

45. Smith JB, Ash KO, Hunt SC, Hentschel WM, Sprowell W, Dadone MM, Williams RR: Three red cell sodium transport systems in hypertensive and normotensive Utah adults. Hypertension 6: 159, 1984

46. Duhm J, Göbel BO, Lorenz R, Weber PC: Sodium-lithium exchange and sodium-potassium cotransport in human erythrocytes. Part 2: a simple uptake test applied to normotensive and essential hypertensive individuals. Hypertension 4: 477, 1982

47. Wiley JS, Clarke DA, Bonacquisto LA, Scarlett JD, Harrap SB, Doyle AE: Erythrocyte cation cotransport and countertransport in essential hypertension. Hypertension 6: 360, 1984

48. Vakakis N, Redgrave TG, Small DM, Castelli WP: Cholesterol content of red blood cells and low-density lipoproteins in hypertriglyceridemia. Biochim Biophys Acta 751:280, 1983

49. Rifkind BM, Tamir I, Heiss G, Wallace RB, Tyroler HA: Distribution of high density and other lipoproteins in selected LRG prevalence study populations: a brief survey. Lipids 14: 105,1979

50. Brugnara C, Corrocher R, Foroni L, Steinmayr M, Bonfanti F, De Sandre G: Lithiumsodium countertransport in erythrocytes of normal and hypertensive subjects. Relationship with age and plasma renin activity. Hypertension 5: 529, 1983

51. Hass M, Schmidt WF III, McManus TJ: Catecholamine-stimulated ion transport in duck red cells: gradient effects in electrically neutral $[\mathrm{Na}+\mathrm{K}+2 \mathrm{Cl}]$ cotransport. J Gen Physiol 80: 125,1982

52. Goldinger JM, Kang BS, Choo YE, Paganelli CV, Hong SK: Effect of hydrostatic pressure on ion transport and metabolism in human erythrocytes. J Appl Physiol Respir Environ 49: 224,1980

53. Goto E: Relation of sodium concentrations in cerebrospinal fluid to arterial blood pressure levels in salt-sensitive and nonsalt-sensitive patients with essential hypertension. J Jap Soc Intern Med 71: 1529, 1982

54. Takishita S, Ferrario $\mathrm{C}$ : Lack of interaction between a hypertonic NaCl stimulus and the brain renin-angiotensin system. Am J Physiol 244: H471, 1983

55. Imagawa $M$, Kamei $H$, Arakawa $K$ : High renin low blood pressure and its treatment with calcium glycyrrhetinylglycinate. Jpn Heart J 23: 201, 1982

56. Dupont J, Dupont JC, Froment A, Milon H, Vincent M: Selection of three strains of rats with spontaneously different levels of blood pressure. Biomedicine 19: 36, 1973 